\title{
EFEKTIFITAS PENYULUHAN DENGAN MEDIA POSTER TERHADAP PENINGKATAN PENGETAHUAN TENTANG KEBERSIHAN GIGI PADA SISWA/I KELAS III DAN IV DI SDN 104186 TANJUNG SELAMAT KECAMATAN SUNGGAL TAHUN 2014
}

\author{
Rawati Siregar, Sondang \\ Jurusan Keperawatan Gigi Poltekkes Kemenkes Medan
}

\begin{abstract}
Abstrak
Umumnya pendidikan kesehatan gigi dan mulut diperoleh melalui penyuluhan. Kelompok masyarakat yang sering dituju adalah anak-anak sekolah dasar, karena usia 6-14 tahun merupakan usia transisi atau pergantian gigi permanen (masa gigi bercampur) . Penyuluhan yang diberikan adalah penyuluhan dengan media poster yang bertujuan untuk meningkatkan pengetahuan tentang kebersihan gigi pada sisiwa/i kelas III dan IV di SDN 104186 Tanjung Selamat kecamatan Sunggal.Penelitian ini besifat deskriptif, sampel adalah seluruh siswa/i kelas III dan IV SDN 104186 tanjung Selamat Kecamatan Sunggal yang berjumlah 50 orang.Dari hasil penelitian yang didapatkan dengan cara pengisian kuisioner maka hasilnya adalah sebagai berikut : yang berpengetahuan baik pada kelas III sesudah penyuluhan berjumlah 19 orang (76\%), dan yang berpengetahuan baik pada kelas IV berjumlah 22 orang $(88 \%)$.Dapat ditarik kesimpulan bahwa penyuluhan yang diberikan dengan media poster dapat meningkatkan pengetahuan siswa/i tentang kebersihan gigi.
\end{abstract}

Kata kunci: penyuluhan, Media Poster, Kebersihan Gigi

\section{PENDAHULUAN}

Dalam undang-undang kesehatan No.36 tahun 2009 memberikan batasan kesehatan adalah keadaan sehat, baik secara fisik, mental spiritual maupun sosial yang memungkinkan setiap orang untuk hidup produktif secara sosial dan ekonomi. Batasan yang diangkat dari batasan kesehatan menurut organisasi kesehatan dunia (WHO) yang paling baru ini memang lebih luas dan dinamis dibandingkan dengan batasan sebelumnya yang mengatakan, bahwa kesehatan adalah keadaan sempurna, baik fisik, mental, maupun sosial, dan tidak hanya bebas dari penyakit dan cacat. Pada batasan yang terdahulu, kesehatan itu hanya mencakup tiga aspek, yakni : fisik, mental, dan sosial tetapi menurut undang-undang No.23/1992, disempurnakan dengan UU No.36 tahun 2009 kemudian kesehatan itu mencakup lima aspek yakni fisik (badan), mental (jiwa), sosial, spritual dan ekonomi(Notoatmojo,2012)

Kesehatan adalah keadaan sejahtera dari badan, jiwa, dan sosial yang memungkinkan setiap orang hidup produktif secara sosial dan ekonomi. Sedangkan istilah sehat dalam kehidupan sehari-hari sering di pakai untuk menyatakan bahwa sesuatu dapat bekerja secara normal.

Kesehatan gigi dan mulut merupakan bagian dari kesehatan tubuh yang tidak dapat dipisahkan satu sama lainnya. Prevalensi penduduk yang mempunyai masalah kesehatan gigi dan mulut adalah $23 \%$ dan $1,6 \%$ penduduk telah kehilangan gigi aslinya. Dari jumlah yang menerima perawatan atau pengobatan dari tenaga kesehatan adalah 29,6\% (Riskesdas,2007)
Gigi merupakan salah satu elemen yang tak boleh terlupakan sebagai satu kesatuan pendukung penampilan yang sempurna. Namun, sampai saat ini masih banyak masyarakat yang melupakan pentingnya kebersihan dan kesehatan gigi. Dan, tak hanya orang dewasa saja yang terbilang malas menjaga kesehatan dan kebersihan giginya dengan cara menyikat gigi.

Menurut penelitian yang dilakukan di singapura dan di indonesia pada tahun 2007, 8 dari 10 anak sekolah dasar sudah mengalami masalah gigi berlubang. Yang lebih memprihatinkan lagi, penelitian ini mengungkapkan bahwa anak-anak indonesia di usia lima tahun sudah mengalami gigi berlubang pada tiga giginya. Hal ini menunjukkan bahwa kesadaran untuk menjaga kesehatan dan kebersihan gigi di indonesia masih tergolong rendah. Padahal sebenarnya gigi bisa menjadi indikasi tingkat kesehatan masyarakat secara umum disuatu tempat.

Kesehatan gigi dan mulut sangat penting sekali dan harus dijaga semenjak masih kecil. Gigi adalah suatu alat bantu pencernaan kita yang mempunyai fungsi amat penting. Dengan gigi, maka proses mengunyah makanan menjadi lebih mudah. Dengan gigi pula kita dapat menggigit atau pun menyobek apa-apa yang dimakan.

Promosi kesehatan di sekolah merupakan suatu upaya untuk menciptakan sekolah menjadi suatu komunitas yang mampu meningkatkan derajat kesehatan masyarakat sekolah melalui kegiatan utama, yaitu : (a) pen ciptaan lingkungan sekolah yang sehat, (b) pemeliharaan dan pelayanan di sekolah, dan (c) upaya pendidikan yang berkesinambungan. Ketiga kegiatan tersebut dikenal dengan istilah TRIAS UKS (Kholid, 2012) 
Pendidikan kesehatan gigi (PKG) di sekolah melalui TotalQualityManagement (TQM) merupakan suatu sistem pendidikan nonformal bagi masyarakat sekolah dengan cara belajar sambil berbuat (learning by doing) untuk mengubah perilaku mereka dari yang kurang menguntungkan menjadi menguntungkan terhadap kesehatan gigi dan mulutnya. Melalui kegiatan ini diharapkan mereka menjadi tahu, mau, dan mampu memecahkan berbagai persoalan yang dihadapi, baik secara sendiri maupun bersama, guna terus meningkatkan kesehatan gigi dan mulutnya sendiri serta keluarganya. Pengertian PKG di sekolah melalui TQM adalah suatu sistem pendidikan nonformal bagi masyarakat sekolah yang berorientasi pada kebutuhan serta memberi kesempatan pada mereka untuk berpartisipasi aktif dalam merencanakan, mengorganisasikan, melaksanakan, dan mengevaluasi program-program kesehatan gigi(Astoeti, 2006)

Penyuluhan kesehatan adalah kegiatan pendidikan kesehatan, yang dilakukan dengan menyebarkan pesan, menanamkan keyakinan, sehingga masyarakat tidak saja sadar, tahu dan mengerti, tetapi juga mau dan bisa melakukan suatu anjuran yang ada hubungannya dengan kesehatan (Azwar,1983).

Survey awal yang telah dilakukan di SDN 104186 Tanjung Selamat Kecamatan Sunggal Tahun 2014 peneliti banyak menemukan permasalahan banyaknya gigi siswa/i yang kotor, disebabkan karena mereka tidak menjaga kebersihan giginya.

Berdasarkan latar belakang diatas dan dengan melihat survey awal di SDN 104186 Tanjung Selamat Kecamatan Sunggal Tahun 2014 maka peneliti tertarik untuk mengetahui apakah efektifitas penyuluhan dengan media poster dapat meningkatkan pengetahuan siswa/i tentang kebersihan gigi di SDN 104186 Tanjung Selamat Kecamatan Sunggal Tahun 2014.

\section{Tujuan Penelitian}

Untuk mengetahui efektifitas penyuluhan dengan media poster terhadap peningkatan pengetahuan tentang kebersihan gigi pada siswa/i kelas III dan IV di SDN 104186 Tanjung Selamat Kecamatan Sunggal Tahun 2014.

\section{Manfaat Penelitian}

1. Hasil penelitian ini diharapkan dapat dimanfaatkan sebagai bahan masukan dalam perencanaan UKGS dan pelayanan penyuluhan kesehatan gigi dan mulut di SDN 104186 Tanjung selamat Kecamatan Sunggal.

2. Hasil penelitian ini diharapkan dapat meningkatkan kesadaran siswa/i di SDN 104186 Tanjung selamat Kecamatan Sunggal terhadap kebersihan gigi dan mulut.

3. Penelitian ini diharapkan dapat menjadi masukan kepada pihak sekolah SDN 104186 Tanjung Selamat Kecamatan Sunggal.

4. Hasil penelitian ini diharapkan dapat menyediakan data dan informasi bagi peneliti yang sejenisnya

\section{METODE PENELITIAN}

\section{Jenis Dan Desain Penelitian}

Jenis penelitian yang akan dilakukan adalah penelitian deskriptif dengan metode survey untuk mengetahui efektifitas penyuluhan dengan media poster terhadap peningkatan pengetahuan tentang kebersihan gigi.pada siswa/i SDN 104186 Tanjung Selamat Kecamatan Sunggal Tahun 2014.

\section{Populasi dan Sampel Penelitian}

Menurut Notoadmojo bahwa populasi adalah keseluruhan subjek penelitian. Populasi dari penelitian ini adalah seluruh siswa/i kelas III dan IV di SDN 104186 Tanjung Selamat Kecamatan Sunggal Tahun 2014. Jumlah populasi pada penelitian ini adalah 50 orang siswa.

Sampel adalah sebagian yang diambil dari keseluruhan objek yang akan diteliti di anggap mewakili seluruh populasi. Dalam pengambilan sampel dalam hal ini peneliti mengacu kepada pendapat Arikunto, 2006 yaitu apabila subjek kurang dari 100 ,lebih baik diambil semua sehingga penelitiannya merupakan penelitian populasi, maka sampel penelitian ini adalah seluruh populasi yaitu 50 orang siswa/i kelas III dan IV SDN 104186 Tanjung Selamat Kecamatan Sunggal Tahun 2014 karena kurang dari 100 orang.

\section{HASIL DAN PEMBAHASAN}

\section{Hasil penelitian}

Data yang dikumpulkan adalah data hasil penelitian yang dilakukan terhadap siswa/i SDN 104186 Tanjung Selamat Kecamatan Sunggal Tahun 2014. Penelitian langsung di lakukan kepada siswa/i dengan memberikan dua kali kuesioner sebelum penyuluhan dan sesudah penyuluhan dengan media poster. Dari penelitian yang dilakukan maka, skor pengetahuan sebelum dan sesudah dilakukan penyuluhan dengan media poster ada perbedaan. Setelah data terkumpul, maka dilakukan analisa data dengan membuat tabel distribusi frekuensi sebagai berikut :

Tabel A.1

Distribusi Frekuensi Pengetahuan Tentang Kebersihan GigiSebelum Penyuluhan Dengan Media Poster Kepada Siswa/i Kelas III SDN 104186 Tahun 2014

\begin{tabular}{cccc}
\hline NO & Kriteria & N & \% \\
\hline 1 & Baik & 8 & 32 \\
2 & Sedang & 17 & 68 \\
3 & Buruk & 0 & 0 \\
\hline & Jumlah & 25 & 100 \\
\hline
\end{tabular}

Dari tabel diatas menunjukkan tingkat pengetahuan siswa/i sebelum dilakukan penyuluhan dengan media poster menunjukkan yang berpengetahuan baik sebanyak 8 orang (32\%), yang memiliki pengetahuan sedang sebanyak 17 orang (68\%), dan tidak ada yang berpengetahuan buruk. 
Tabel A.2

Distribusi FrekuensiPengetahuan Tentang Kebersihan Gigi SesudaPenyuluhan Dengan Media Poster Kepada Siswa/i Kelas III SDN 104186 Tahun 2014

\begin{tabular}{cccc}
\hline NO & Kriteria & N & \% \\
\hline 1 & Baik & 19 & 76 \\
2 & Sedang & 6 & 24 \\
3 & Buruk & 0 & 0 \\
\hline & Jumlah & 25 & 100 \\
\hline
\end{tabular}

Dari tabel diatas menunjukkan bahwa tingkat pengetahuan sesudah penyuluhan dengan media poster, menunjukkan yang berpengetahuan baik naik menjadi 19 orang $(76 \%)$ yang berpengetahuan sedang turun menjadi 6 orang (24\%) dan tidak ada yang berpengetahuan buruk.

Tabel A.3

Distribusi Frekuensi Pengetahuan Tentang Kebersihan GigiSebelum Penyuluhan Kepada Siswa/i Kelas IV SDN 104186 Tahun 2014

\begin{tabular}{cccc}
\hline NO & Kriteria & N & \% \\
\hline 1 & Baik & 10 & 40 \\
2 & Sedang & 15 & 60 \\
3 & Buruk & 0 & 0 \\
\hline & Jumlah & 25 & 100 \\
\hline
\end{tabular}

Dari tabel diatas menunjukkan tingkat pengetahuan sebelum penyuluhan dengan media poster, menunjukkan yang berpengetahuan baik sebanyak 10 orang $(40 \%)$ sedangkan berpengetahuan sedang sebanyak 15 orang (60\%) dan tidak ada yang berpengetahuan buruk.

Tabel A.4

Distribusi Frekuensi Pengetahuan Tentang Kebersihan GigiSesudah Penyuluhan Dengan Media Poster Kepada Siswa/i kelas IV SDN 104186 Tahun 2014

\begin{tabular}{cccc}
\hline NO & Kriteria & N & \% \\
\hline 1 & Baik & 22 & 88 \\
2 & Sedang & 3 & 12 \\
3 & Buruk & 0 & 0 \\
\hline & Jumlah & 25 & 100 \\
\hline
\end{tabular}

Dari tabel diatas menunjukkan bahwa tingkat pengetahuan siswa/i sesudah penyuluhan dengan media poster, menunjukkan yang berpengetahuan baik meningkat menjadi menjadi 22 orang $(88 \%)$, yang berpengetahuan sedang turun menjadi 3 orang (12\%), dan tidak ada yang berpengetahuan buruk.
Tabel A.5

Distribusi Frekuensi Perbedaan Pengetahuan

Tentang Kebersihan Gigi Sebelum Dan Sesudah Penyuluhan Dengan Media Poster Pada Siswa /I Kelas III Dan IV Di SDN 104186 Tahun 2014

\begin{tabular}{cccc}
\hline Kelas & $\begin{array}{l}\text { Sebelum } \\
\text { Penyuluhan }\end{array}$ & $\begin{array}{l}\text { Sesudah } \\
\text { Penyuluhan }\end{array}$ & 'erbedaan \\
\hline III & 8 & 19 & 11 \\
IV & 10 & 22 & 12 \\
\hline
\end{tabular}

Dari tabel diatas kita ketahui perbedaan pengetahuan sebelum dan sesudah penyuluhan dengan media poster. Pada kelas III didapat perbedaannya yaitu 11 atau $1: 2$ dan perbedaan pada kelas IV yaitu 12 atau $1: 2$. Seperti terlihat pada tabel diatas terdapat peningkatan angka pengetahuan sebelum dan sesudah penyuluhan dengan media poster.

\section{PEMBAHASAN}

Pada siswa/i kelas III SDN 104186 Tanjung Selamat Kecamatan Sunggal, Tingkat pengetahuan sebelum dilakukan penyuluhan tentang kebersihan gigi dengan media poster pada kelas III adalah berpengetahuan baik sebanyak 8 orang, yang memiliki pengetahuan sedang sebanyak 17 orang, dan tidak ada yang berpengetahuan buruk. Dan sesudah dilakukan penyuluhan tentang kebersihan gigi dengan media poster menunjukkan yang berpengetahuan baik naik menjadi 19 orang, yang berpengetahuan sedang turun menjadi 6 orang dan tidak ada yang berpengetahuan buruk. Perbedaan sesudah dan sebelum penyuluhan adalah

Pada siswa/i kelas IV SDN 104186 Tanjung Selamat Kecamatan Sunggal tingkat pengetahuan sebelum dilakukan penyuluhan tentang kebersihan gigi dengan media poster adalah menunjukkan yang berpengetahuan baik sebanyak 10 orang sedangkan berpengetahuan sedang sebanyak 15 orang dan tidak ada yang berpengetahuan buruk. Dan sesudah dilakukan penyuluhan tentang kebersihan gigi dengan media poster adalah menunjukkan yang berpengetahuan baik meningkat menjadi menjadi 22 orang , yang berpengetahuan sedang turun menjadi 3 orang, dan tidak ada yang berpengetahuan buruk.

Perbedaannya pengetahuan sebelum dan sesudah dilakukan penyuluhan tentang kebersihan gigi dengan media poster yaitu 8 meningkat menjadi 19 atau $1: 2$ dan perbedaan pada kelas IV yaitu 12 meningkat menjadi 22 atau $1: 2$. terdapat peningkatan angka pengetahuan sebelum dan sesudah penyuluhan dengan media poster. 
Menurut Maulana (2009) faktor-faktor yang sangat mempengaruhi dalam penyuluhan kesehatan adalah dalam aspek pemilihan metode, alat bantu/media, dan jumlah kelompok sasaran, artinya untuk mendapatkan hasil penyuluhan dengan maksimal ketiga faktor tersebut sangat mempengaruhi. Media yang digunakan ditentukan oleh intensitas media tersebut dalam memberikan pengalaman belajar kepada siswa, poster sarat dengan tampilan visual gambar, sehingga lebih melibatkan indera ketika menerima materi penyuluhan, maka tingkat siswa dalam menangkap pesan atau materi penyuluhan akan semangkin efektif. (Depkes RI, 2008)

Media poster dapat lebih efektif sebagai media penyuluhan karena lebih membatu menstimulasi indera penglihatan siswa, aspek visual pada gambar-gambar poster lebih memudahkan penerimaaan informasi atau materi pendidikan (Notoadmojo, 2004)

Hasil penelitian ini membuktikan bahwa penyuluhan kesehatan gigi pada anak-anak lebih baik dilakukan dengan media poster Hal senada dikemukakan oleh Saptarini (2005) bahwa pesan visual berupa gambar lebih mudah tertanam dalam pikiran audience dibandingkan dengan kata-kata, sehingga penyuluhan kesehatan gigi tentang cara memelihara kesehatan gigi dapat lebih efektif jika menggunakan media yang lebih banyak menanmpilkan gambar, terlebih pada sasaran audience siswa sekolah dasar.

\section{SIMPULAN DAN SARAN}

\section{Simpulan}

Dari hasil penelitian yang telah di lakukan,diperoleh maka simpulannya sebagai berikut :

1. Tingkat pengetahuan siswa/i kelas III SDN 104186 Tanjung selamat Kecamatan Sunggal, setelah dilakukan penyuluhan dengan menggunakan media poster tentang pengetahuan kebersihan gigi yang berpengetahuan baik adalah 19 siswa (76\%), sedangkan yang berpengetahuah sedang adalah 6 siswa (24\%) . Ini menunjukkan bahwa tingkat pengetahuan tentang kebersihan gigi pada siswa/i sudah baik.

2. Tingkat pengetahun siswa/i kelas IV SDN 104186 Tanjung selamat Kecamatan Sunggal, setelah dilakukan penyuluhan dengan menggunakan media poster tentang pengetahuan kebersihan gigi yang berpengetahuan baik adalah 22 siswa (88\%), sedangkan yang berpengetahuan sedang adalah 3 siswa (12\%) . ini menunjukkan bahwa tingkat pengetahuan tentang kebersihan gigi pada siswa/i sudah baik.
3. Perbedaan pengetahuan sebelum dan sesudah penyuluhan tentang kebersihan gigi dengan media poster yaitu Pada kelas III meningkat lebih baik yaitu dari 8 menjadi 19. Dan pada kelas IV juga meningkat lebih baik yaitu dari 10 menjadi 22 .

\section{Saran}

1. Disarankan agar penyuluhan kesehatan gigi dan mulut pada anak-anak lebih baik dilakukan dengan media poster karena dengan melihat gambar membuat proses belajar mengajar menjadi mudah dimengerti dan menjadi lebih aktif juga menyenangkan sehingga cocok digunakan pada anak-anak.

2. Diharapkan adanya dukungan dari pihak sekolah untuk membuat Program Usaha kesehatan Gigi Sekolah (UKGS) sehingga dokter atau perawat gigi dapat berperan aktif dalam mengedukasikan dan mengontrol kesehatan gigi dan mulut pada siswa/i dan akhirnya menimbulkan kebiasaan yang lebih baik dalam merawat gigi dan mulutnya.

\section{DAFTAR PUSTAKA}

Arikunto, S.,2006,ProsedurPenelitian Suatu pendekatan Praktik, PT. Rineka, Cipta. Jakarta.

Astoeti.,2006, Pendidikan Kesehatan Gigi Di Sekolah, Rajawali Pers, Jakarta

Herjulianti., dkk, 2006, Pendidikan Kesehatan Gigi, Buku Kedokteran EGC: Jakarta.

Kholid, A.,2012, Promosi Kesehatan, Rajawali Pers: Jakarta.

Machfoedz, I., dkk. 2009. Pendidikan Promosi Kesehatan, Fitramaya: Yogyakarta.

Notoadmojo, S., 2012, Promosi Kesehatan Dan Perilaku Kesehatan, Bineka Cipta: Jakarta. 2010, Metode Penelitian Kesehatan, Bineka Cipta: Jakarta

Budiharto., 2008, Ilmu Perilaku Kesehatan dan Pendidikan Kesehatan Gigi. Buku Kedokteran EGC: Jakarta.

Suiraoka, P., dkk, 2012, Media Pendidikan Kesehatan, Graha Ilmu: Yogyakarta.

Richahardiyanti22.blogspot.com 2013.

http://www.sarjanaku.kompas.com.://female.kompas.com/r ead/2012/05/10/17022744/3.penyebab.utama.g igi.berlubang.

http://buahuntukdiet.com

http://.pengertianahli.com/2013/12/pengertian-poster-apaitu-poster.html

http://ibnuabihurairah.blogspot.com/2011/04/pen yuluhan-kesehatan-gigi-andi.html. 